\title{
Pendampingan Pendidikan Karakter Mahasiswa HMPS PGSD Universitas Mataram dalam Kegiatan Kemah Bakti Masyarakat
}

\author{
Radiusman', Muhammad Erfan*2, Deni Sutisna ${ }^{3}$, Muhammad Syazali, Muhammad Sobri ${ }^{5}$ \\ 1,2,3,4,5Program Studi Pendidikan Guru Sekolah Dasar, Fakultas Keguruan dan Ilmu Pendidikan, Universitas \\ Mataram \\ *e-mail: radius saragih88@unram.ac.id ${ }^{1}$, muhammaderfan@unram.ac.id $^{2}$, denisutisna@unram.ac.id ${ }^{3}$, \\ $\underline{\text { m.syazali@unram.ac.id }}{ }^{4}, \underline{\text { muhammad.sobri@unram.ac.id }}^{5}$
}

\begin{abstract}
Community Service Camp (KBM) is an annual activity carried out by HMPS PGSD, Mataram University. The purpose of this KBM activity is to assist partner village communities in solving problems in partner villages by implementing character education obtained by HMPS PGSD students at Mataram University in lectures. KBM activities are carried out in Batu Pasir hamlet. KBM activities take place for a week. The methods used by students before conducting a CBC are location surveys, interviews with community officials and ending with asking permission from community officials to conduct a $C B C$. The problem in this partner village is the lack of teachers reading Al-Quran, building hamlet prayers, and improving MCK facilities. The KBM program is carried out by a team of servants with HMPS students and is assisted by elements of the community. Activities take place smoothly and successfully. This was obtained through the results of interviews with the hamlet and the surrounding community who felt helped by the existence of KBM activities carried out in the Batu Pasir hamlet.
\end{abstract}

Keywords: Character Education, implementation, Community Service Camps

\begin{abstract}
Abstrak
Kegiatan kemah Bakti Masyarak (KBM) merupakan kegiatan tahunan yang dilakukan oleh HMPS PGSD Universitas Mataram. Tujuan kegiatan KBM ini adalah membantu masyarakat desa mitra dalam menyelesaikan permasalahan di desa mitra tersebut dengan cara mengimplementasikan pendidikan karakter yang diperoleh oleh mahasiswa HMPS PGSD Universitas Mataram di dalam perkuliahan. Kegiatan KBM dilakukan di dusun Batu Pasir. Kegiatan KBM berlangsung selama seminggu. metode yang dilakukan mahasiswa sebelum melakukan KBM adalah survey lokasi, wawancara dengan perangkat masyarakat dan diakhiri dengan meminta ijin kepada perangkat masyarakat untuk melakukan KBM. Adapun permasalahan yang terdapat di desa mitra ini adalah kurangnya guru membaca Al-Quran, pembangunan mushola dusun, serta perbaikan fasilitas MCK. Program KBM dilakukan oleh tim pengabdi Bersama mahasiswa HMPS dan dibantu oleh unsur masyarakat. Kegiatan berlangsung dengan lancar dan berhasil. Hal ini diperoleh dengan melalui hasil wawancara dengan perangkat dusun serta masyarakat sekitar yang merasa terbantu dengan adanya kegiatan KBM yang dilaksanakan di dusun Batu Pasir.
\end{abstract}

Kata kunci: Pendidikan Karakter, implementasi, Kemah Bakti Masyarakat

\section{PENDAHULUAN}

Permasalahan karakter generasi muda di Indonesia akhir-akhir ini mendapat sorotan yang tajam. Hal ini terbukti dengan banyaknya tindakan kriminal yang dilakukan oleh generasi muda baik secara individual maupun kelompok, seperti mencuri, menggunakan narkoba, tawuran, seks bebas dan sebagainya. Banyak faktor yang mempengaruhi perkembangan karakter generasi muda di indonesia, salah satunya adalah kemajuan teknologi. Kemajuan teknologi yang ada di dunia terkadang tidak dapat disikapi secara bijak dan positi oleh anak-anak generasi muda. Banyak anak-anak yang menggunakan kemajuan teknologi hanya untuk hal-hal yang negatif dan merugikan orang lain. Ketidaksanggupan generasi muda dalam menyikapi perkembangan teknologi secara positif menimbulkan adanya permasalahan karakter tersebut yang akhirnya berdampak kepada krisis moral serta perilaku negatif dalam masyarakat.

Agustian (2010) menyatakan bahwa krisis moral yang sedang berlangsung di tengahtengah masyarakat Indonesia antara lain krisis disiplin, krisis keadilan, krisis tanggung jawab, tidak memikirkan jauh kedepan, krisis kejujuran, dan krisis kebersamaan. Permasalahan krisis moral diawali dengan adanya kondisi yang buruk di dalam keluarga. Orang tua kurang memberi 
dalam memberi perhatian tumbu kembang anak, sehingga dalam perkembangannya anak-anak tidak memiliki perkembangan moral yang baik. Perkembangan krisis moral yang ada dikalangan muda dapat memberikan dampak negatif di tengah-tengah masyarakat dan lingkungan. Perkembangan krisis moral yang berkembang dalam masyarakat akan mengakibatkan munculnya tindakan yang tidak bermoral (amoral). Tindakan amoral merupakan suatu tindakan yang tidak acuh terhadap harapan sosial akibat kurangnya pemahaman terhadap peraturan yang berlaku dalam masyarakat (Pertiwi, 2018). Sikap amoral yang ada di kalangan anak muda harus segera diselesaikan, salah satunya melalui Pendidikan. Pendidikan di harapkan dapat membantu menanamkan nilai-nilai moral yang baik kepada anak (Ermayani, 2016).

Pendidikan merupakan suatu proses yang disengaja, dirancang sesuait dengan aturan yang berlaku serta disepakati oleh berbagai pihak (Omeri, 2015). Pendidikan juga bertujuan untuk mengembangkan kualitas generasi muda bangsa dalam berbagai bidang sehigga dapat mengurangi permasalahan bangsa. Pendidikan memiliki peranan yang sangat penting dalam pembentukan karakter setiap individu (Pradana, 2016). Pendidikan karakter dapat diajarkan oleh berbagai pihak dan berbagai lingkungan di dalam kehidupan sehari-hari. Pendidikan karakter juga menjadi salah satu tujuan dari Pendidikan nasional. pendidikan karakter merupakan proses mengembangkan sikap dan perilaku yang memperlihatkan budi pekerti di dalam masyarakat (Suwandayani \& Isbadrianingtyas, 2017).

Pendidikan karakter harus dimulai dan dibentuk sejak usia dini (Setiawati, 2017). Pada usia dini anak berada pada fase golden ages, dimana perkembangan fisik bersamaan dengan masa peka (Filtri, Bastian, \& Reswita, 2017). Pendidikan karakter dapat dilakukan di berbagai lingkungan kegiatan, antara lain lingkungan sekolah. Pendidikan di lingkungan sekolah merupakan salah satu upaya mendidik generasi muda yang mandiri, bertanggung jawab, memiliki akhlak yang baik, serta berilmu (Laksana, 2015). Hal Ini juga sejalan dengan UU No 20 Tahun 2003 yang menyatakan bahwa salah satu fungsi dari tujuan Pendidikan nasional adalah mengembangkan kemampuan dan membentuk watak (karakter) yang bertujuan untuk menjadikan manusia indonesia menjadi manusia yang beriman dan bertakwa kepada Tuhan YME, berakhlak mulia, sehat, berilmu, cakap, kreatif,responsif, memiliki kepedulian, memiliki sikap gotong royong, suka menolong, demokratis dan memiliki tanggung jawab.

Pembentukan watak generasi muda dapat dibentuk melalui pendidikan. Lingkungan Pendidikan merupupakn suatu tempat yang sangat efektif dalam pembentukan karakter (Supraptiningrum \& Agustini, 2015). Pembentukan karakter yang dilakukan dalam kegiatan perkuliahan di dalam universitas serta dapat diaplikasi dalam masyarakat dalam bentuk berbagai kegiatan, salah satunya kegiatan kuliah lapangan. Melalui kegiatan perkuliahan lapangan mahasiswa dapat melakukan kegiatan interaksi dengan masyarakat sekitar. Kegiatan interaksi dalam masyarakat dapat dilakukan dengan cara ikut melakukan kegiatan gotong royong, pembangunan fasilitas serta menjadi guru bantu di sekolah yang masih kekurangan pengajar. Salah satu kegiatan perkuliahan lapangan yang dapat digunanakan untuk membentuk karakter mahasiswa PGSD universitas mataram adalah melakukan program kemah bakti masyarakat.

Kemah Bakti Masyarakat (KBM) merupakan salah satu kegiatan tahunan yang dilakukan oleh himpunan mahasiswa PGSD Universitas Mataram. Kegiatan KBM ini dilakukan di tempattempat yang berbeda di setiap tahunnya. Pemilihan tempat KBM dilakukan dilakukan dengan cara melakukan survey lokasi serta wawancara dengan perangkat desa mengenai masalah yang ada di dalam desa serta menawarkan bantuan kepada perangkat desa menyelesaikan permasalahan di tempat tersebut. Kegiatan yang dilakukan mahasiswa PGSD dalam usaha mengaplikasikan pendidikan karakter yang diperoleh selam perkuliahan di dalam masyarakat. Kegiatan KBM ini dilakukan ketika mahasiswa tidak ada perkulihan di lingkungan universitas, Sehingga kegiatan ini dilakukan pada liburan semester.

Pada tahun ini, program KBM mahasiswa PGSD Universitas Mataram beserta tim pengabdi dilakukan di dusun Batu Butir. Dusun Batu Butir merupakan salah suatu daerah yang terletak desa Kekait, Lombok Barat. Dusun Kekait ini memiliki jalan desa yang tidak terlalu bagus, dimana jalan 
desa terdiri dari aspal yang sudah rusak, saluran air di dusun ini tidak terlalu bagus. Berdasarkan hasil survey dan wawancara yang dilakukan dengan perangkat desa setempat, diperoleh bahwa dusun Batu Pasir ini tidak memiliki saluran irigasi yang baik. Hal ini juga ditandai dengan banyaknya air yang menggenang di jalan. Selain itu Dusun Batu Pasir ini memiliki mushola yang sedang dalam pembangunan. Berdasarkan hasil survey dan wawancara tersebut maka mahasiswa PGSD memutuskan untuk memilih dusun Batu Pasir menjadi tempat untuk mengaplikasikan pendidikan karakter yang diperoleh selama perkuliahan.

\section{METODE}

Kegiatan pengabdian masyarakat dilaksanakan di dusun Batu Pasir selama satu minggu. Adapun metode yang dilakukan mahasiswa sebelum melakukan KBM adalah survey lokasi, wawancara dengan perangkat masyarakat dan diakhiri dengan meminta ijin kepada perangkat masyarakat untuk melakukan KBM. Setelah melakukan kegiatan survey dan wawancara dengan perangkat masyarakat maka diperoleh informasi bahwa masalah yang dihadapi di desa mitra adalah kurangnya kegiatan belajar mengaji kepada anak-anak, adanya mushola yang masih dalam tahap pembangunan serta adanya saluran pembuangan air yang masih bermasalah. Maka perlu adanya solusi untuk menyelesaikan permasalahan tersebut.

Solusi yang ditawarkan oleh tim pengabdi dalam penyelesaian masalah ini adalah menggerakkan mahasiswa HMPS PGSD Universitas Mataram dalam mengimplementasikan pendidikan karakter yang diperoleh selama kegiatan perkuliahan yang dilakukan dengan cara melakukan perbaikan dan pembersihan saluran air serta membantu pembangunan mushola. Penyelesaian masalah ini akan dapat dilaksanakan dengan baik jika adanya kerja sama yang baik antara apparat desa, masyarakat dan mahasiswa PGSD Universitas Mataram, sehingga mahasiswa meminta ijin kepada perangkat desa untuk ikut menyelesaikan permasalahan yang ada di dusun Batu Pasir.

\section{HASIL DAN PEMBAHASAN}

Kegiatan KBM yang dilakukan mahasiswa di dusun Batu Pasir ini diawali dengan melakukan koordinasi dengan perangkat dusun mengenai kegiatan yang akan dilakukan dalam menyelesaikan permasalahan yang ada di dusun mitra. Setelah melakukan kegiatan koordinasi dengan aparat desa, maka diperoleh rencana kegiatan KBM mahasiswa dalam mengimplentasikan pendidikan karakter antara lain melakukan perbaikan dan pembersihan saluran air, membantu percepatam pembangunan mushola serta melakukan kegiatan pengajian kepada anak-anak pada saat malam hari.

Pada hari pertama kegiatan yang dilakukan oleh Sebagian mahasiswa HMPS adalah melakukan kegiatan belajar mengaji kepada anak-anak di dusun Batu Pasir. Kegiatan ini dilakukan setiap malam, setelah melakukan sholat maghrib. Pada kegiatan belajar mengaji ini, HMPS mengajarkan anak-anak dalam membaca ayat-ayat Al-quran. Kegitan mengaji ini dilakukan oleh mahasiswa laki-laki dan mahasiswa perempuan. Hal ini bertujuan agar setiap anak laki-laki mengajar mengaji kepada mahasiswa laki-laki dan anak perempuan mengajar mengaji kepada mahasiswa perempuan. Kegiatan ini dilakukan oleh mahasiswa secara sukarela dan sabar. Kegiatan ini merupakan salah salah satu implementasi pendidikan karakter yaitu menjadikan manusia indonesia menjadi manusia yang beriman dan bertakwa kepada Tuhan YME, suka menolong dan bertanggung jawab. Adapun kegiatan mengaji anak-anak dusun Batu Pasir dapat dilihat pada Gambar 1. 

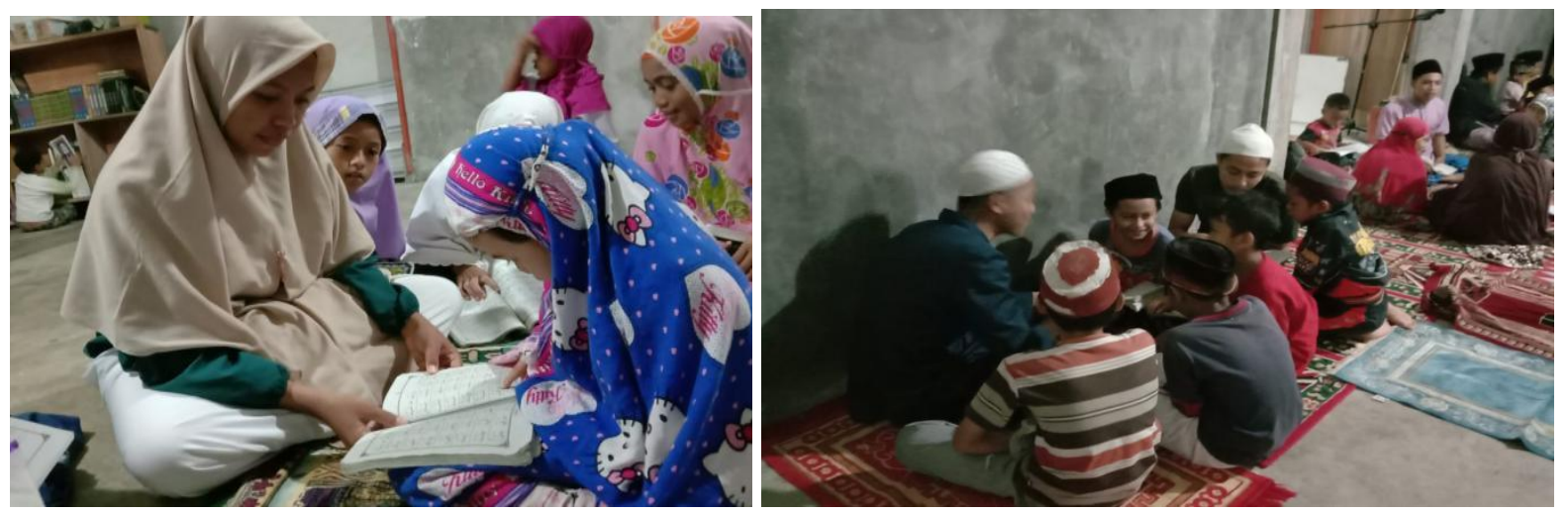

Gambar 1. Kegiatan Mengaji oleh Mahasiswa HMPS

Pada hari berikutnya, kegiatan yang dilakukan mahasiswa adalah membantu percepatan membangun mushola di dusun Batu Pasir. Kegiatan ini dilakukan oleh mahasiswa laki-laki dan pemuda setempat. Adapun kegiatan yang dilakukan oleh mahasiswa adalah menyaring pasir, dan mengaduk campuran semen dan pasir. Kegitan ini merupakan salah satu implementasi Pendidikan karakter yaitu suka menolong, tanggung jawab dan demokratis. Implementasi Sikap gotong royong ditunjukkan pada adanya sikap saling membantu dalam menyelesaikan pekerjaan. Sikap tanggung jawab ditunjukkan pada sikap mahasiswa dalam menyelesaikan pekerjaan, serta sikap demokratis ditunjukkan dengan sikap yang dimiliki mahasiswa dalam menghormati pembagian pekerjaan yang sudah disepakati sebelumnya. Adapun kegiatan pembangunan percepatan mushola dapat dilihat pada Gambar 2.
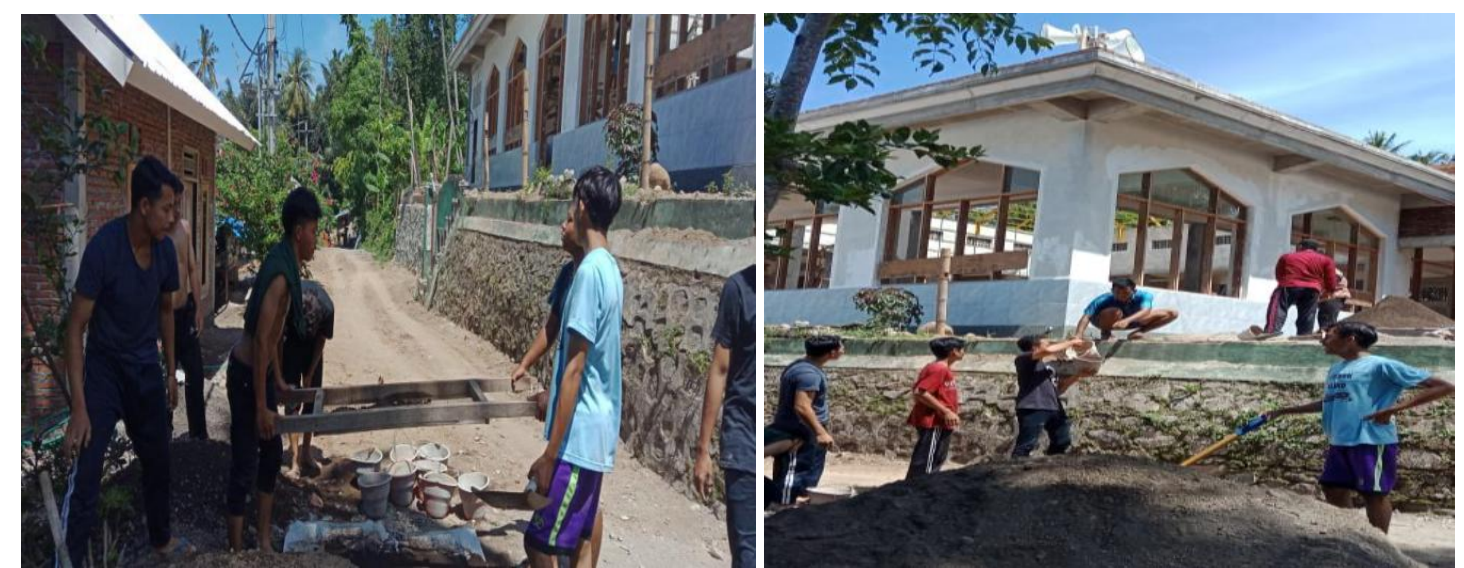

Gambar 2. Mahasiswa Melakukan Kegiatan Pembangunan Mushola

Aktivitas yang dilakukan oleh mahasiswi pada saat ini adalah melakukan kegiatan memasak yang akan dijadikan konsumsi secara Bersama. Pendidikan karakter yang dilakukan oleh mahasiswi ini adalah sikap peduli kepada sesama serta berdemokrasi. Sikap peduli ini ditunjukkan Ketika mahasiswa peduli akan kebutuhan makanan yang dibutuhkan oleh semua anggota HMPS yang melaksanakan kegiatan KBM. Sikap demokrasi ditunjukkan Ketika setiap mahasiswi menerima tugas dan menyelesaikan tugas dengan baik. Adapun kegiatan memasak mahasiswi dapat dilihat pada Gambar 3 . 


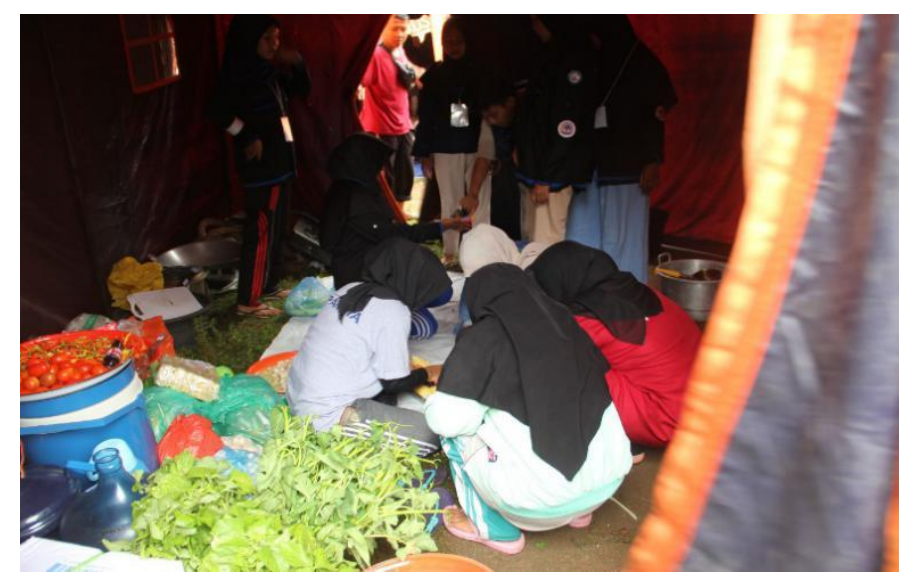

Gambar 3. Kegiatan Memasak Mahasiswi

Pada saat kegiatan KBM berlangsung, mahasiswa mendapat tugas tambahan dari kepala dusun, yaitu membersihkan serta memperbaiki fasilitas MCK yang rusak. Adapun Tindakan yang dilakukan mahasiswa adalah langsung memperbaiki serta membersihkan MCK yang ditugaskan oleh oleh kepala dusun. Adapun Pendidikan karakter yang diterapkan mahasiswa dalam kegiatan ini adalah responsif dan bertanggung jawab. Sikap responsif ditunjukkan ketika mahasiswa cepat tanggap dalam menghadapi permasalahan yang diberikan oleh kepala dusun serta bertanggung jawab ditunjukkan ketika mahasiswa mampu untuk menyelesaikan permasalahan dengan baik. Kegiatan pembersihan dan perbaikan MCK dapat dilihat pada Gambar 4.

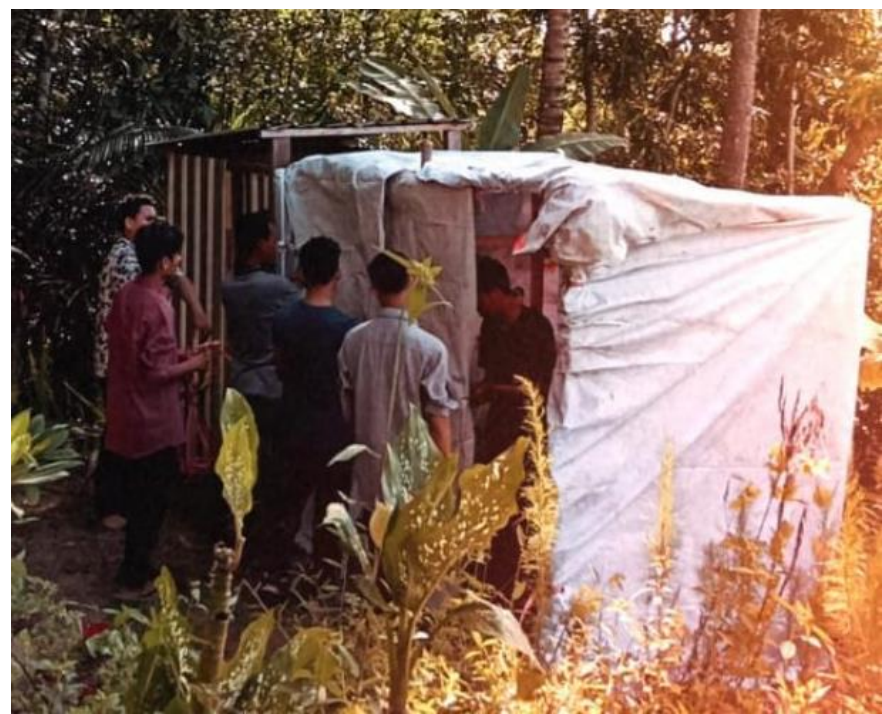

Gambar 4. Kegiatan Mahasiswa dalam Memperbaiki dan Membersihkan MCK

Kegiatan ini berlangsung selama kegiatan KBM berlangsung. Sebelum kegiatan KBM berakhir mahasiswa telah mampu untuk mempercepat pembangunan mushola dan memberikan Pendidikan belajar mengaji kepada anak-anak dusun Batu Pasir. Sebelum kegiatan KBM berakhir, Adapun kegiatan yang dilakukan oleh mahasiswa HMPS PGSD Universitas Mataram melakukan kegiatan bersih-bersih mushola. Pada kegiatan ini mahasiswa melakukan sikap tanggung jawab sebagai aplikasi Pendidikan karakter. Kegiatan tanggung jawab ini dilakukan dengan cara membersihkan alas sholat yang digunakan selama kegiatan KBM dan kegiatan belajar mengaji. Adapun kegiatan kebersihan fasilitas mushola dapat dilihat pada Gambar 5. 


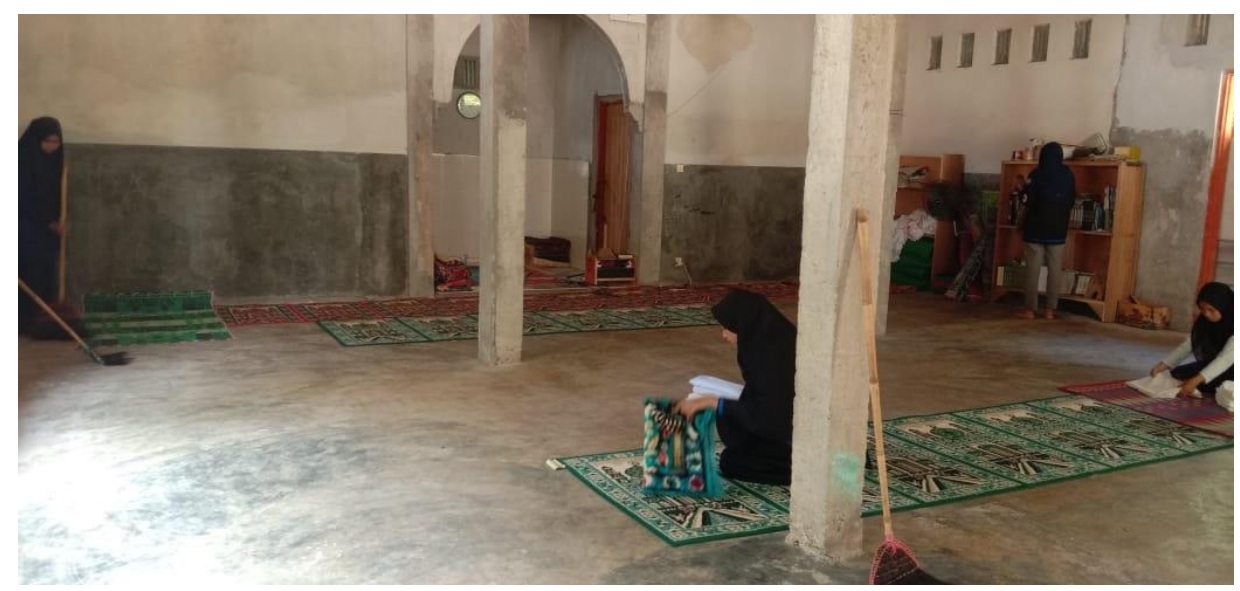

Gambar 5. Kegiatan Pembersihan Fasilitas Mushola

Pada hari terakhir pelaksanaan KBM di dusun mitra, mahasiswa HMPS Universitas Mataram melakukan pertemuan dengan perangkat dusun serta masyarakat sekaligus melakukan wawancara mengenai tingkat kepuasan terhadap kegiatan KBM dengan perangkat desa serta masyarakat sekitar mengenai hal yang dirasakan oleh masyarakat dengan adanya kegiatan KBM. Berdasarkan hasil wawancara dengan perangkat desa dapat diperoleh informasi bahwa masyarakat di dusun mitra sangat terbantu dengan kedatangan tim pengabdi beserta mahasiswa di dusun Batu Pasir, antara lain terbantunya percepatan pembangunan mushola, terbantunya kegiatan pembelajaran di sekolah, pembangunan sarana dusun, serta pembelajaran mengaji kepada anak-anak. Selain itu, perwakilan HMPS juga melakukan wawancara dengan 12 keluarga yang diambil secara acak. Berdasarkan hasil wawancara diperoleh informasi sebagian besar keluarga (83,33\%) merasa terbantu dengan kegiatan KBM. Perangkat dusun beserta masyarakat berharap kegiatan KBM dapat dilaksanakan kembali di dusun Batu Pasir dengan harapan bisa membantu permasalahan yang ada di dusun mitra sekaligus dapat membantu anak-anak dalam kegiatan belajar baik dalam mempelajari pelajaran dari sekolah maupun belajar mengaji di mushola.

\section{KESIMPULAN}

Kesimpulan dari kegiatan pengabdian masyarakat ini adalah dusun mitra terbantu dengan adanya kegiatan KBM yang dilakukan oleh HMPS PGSD Universitas Mataram. Hal ini ditunjukkan dari keterangan yang disampaikan oleh kepala dusun serta wawancara yang dilakukan pada beberapa keluarga bahwa kegiatan tim pengabdi beserta mahasiswa dalam melaksanakan KBM memberikan dampak positif terhadap kemajuan desa serta kemajuan anak-anak dalam mempelajari. Kepala dusun juga memandang kegiatan KBM ini membuat aktivitas warga menjadi lebih semangat dalam melakukan kegiatan sehari-hari serta membantu anak-anak dalam belajar dan bermain.

\section{DAFTAR PUSTAKA}

Agustian, G. (2010). Proceeding Seminar dan Lokakarya Nasional Restrukturisasi Pendidikan Karakter. Yogyakarta: UNY.

Ermayani, T. (2016). Pembentukan Karakter Remaja Melalui Keterampilan Hidup. Jurnal Pendidikan Karakter, 1(2), 127-141. https://doi.org/10.21831/jpk.v0i2.8618

Filtri, H., Bastian, A., \& Reswita, R. (2017). Peran Komunikasi Orangtua dengan Guru dalam Pembentukan Karakter Anak Usia Dini. Dinamisia-Jurnal Pengabdian Kepada Masyarakat, 1(1), 1-4.

Laksana, S. D. (2015). Urgensi Pendidikan Karakter Bangsa Di Sekolah. MUADDIB, 05(01), 167183. 
Omeri, N. (2015). Pentingnya pendidikan karakter dalam dunia pendidikan. Manajer Pendidikan, 9(3), 464-468.

Pertiwi, E. prasetya. (2018). Pendampingan Guru Dalam Pembelajaran "Aspek Nilai Moral Agama Melalui Pendidikan Karakter Dan Pengenalan Pancasila" Di Paud Labschool Jember Tahun Pelajaran 2016-2017. Dinamisia: Jurnal Pengabdian Kepada Masyarakat, 2(1), 113-123. https://doi.org/10.31849/dinamisia.v2i1.761

Pradana, Y. (2016). Pengembangan Karakter Siswa Melalui Budaya Sekolah. UCEJ, 1(1), 55-67.

Setiawati, N. A. (2017). Pendidikan Karakter Sebagai Pilar Pembentukan Karakter Bangsa. Prosiding Seminar Nasional Tahunan Fakulatas Ilmu Sosial Universitas Negeri Medan, 1(1), 348-352. Medan: UNIMED.

Supraptiningrum, supraptiningrum, \& Agustini, A. (2015). Membangun Karakter Siswa Melalui Budaya Sekolah di Sekolah Dasar. Jurnal Pendidikan Karakter, V(2), 219-228.

Suwandayani, B. I., \& Isbadrianingtyas, N. (2017). Peran Budaya Sekolah Dalam pembentuka Karakter Anak Sekolah Dasar. Prosiding SENASGABUD, 34-41. Malang: UMM. 